\title{
Studies Regarding Primary Succession in a Mine Tailing Pond from Bozanta, Maramureș County
}

\author{
Aurel MAXIM ${ }^{1 *}$, Tania MIHAIESCU ${ }^{1}$, Teodor RUSU ${ }^{1}$, Vasile ROMAN ${ }^{1}$, Andrei STOIE ${ }^{1}$, Mignon SANDOR ${ }^{1}$, \\ Larisa BILC ${ }^{1}$, Lucia MIHALESCU ${ }^{2}$, Razvan BENDRE ${ }^{1}$ \\ ${ }^{1}$ Faculty of Agriculture, University of Agriculture Sciences and Veterinary Medicine, Calea Mănăștur no. \\ 3-5, 400372 Cluj-Napoca, Romania \\ ${ }^{2}$ Technical University of Cluj-Napoca, North University Center Baia-Mare, Victoriei St., no. 76, 430122 \\ Baia Mare, Maramureș County, Romania \\ *corresponding author, e-mail: aurel.maxim@usamvcluj.ro
}

Bulletin UASVM series Agriculture 77(1) / 2020

Print ISSN 1843-5246; Electronic ISSN 1843-5386

DOI:10.15835/buasvmcn-agr: 2020.0011

\begin{abstract}
The objective of this study is to carry out a vegetation study at the Bozanta's tailing pond, located $5 \mathrm{~km}$ away from Baia-Mare.Between 2016 and 2017, using the metric frame, the existing species were identified and the following phytocenothic and population indices were determined: presence, frequency, presence classes, and the average abundance-dominance. Soil samples were taken to perform the following physico-chemical analyses: $\mathrm{pH}$, $\mathrm{P}, \mathrm{K}, \mathrm{N}$, humus and heavy metals.The floral inventory shows the presence of six tree species, four species of and 30 herbaceous species. Eleven years after the pond closure, the surface is covered with: $30 \%$ vegetation coverage, $35 \%$ water gloss and the $35 \%$ difference is occupied by arid. The average abundance-dominant synthetic indicator showed that the highest coverage is found in Betula pendula, Salix caprea, and in the grass species, Phragmites australis. The results of physicochemical analyses of the substrate showed very wide ranges of $\mathrm{pH}$ and different amounts of phosphorus, potassium and humus, and low amounts of nitrogen. The presence and concentration of the following heavy metals were determined from three samples: $\mathrm{Cd}, \mathrm{Pb}, \mathrm{Ni}, \mathrm{Cr}$. In regards to lead and chromium level, the alert threshold has not been reached.
\end{abstract}

Keywords: heavy metals, phytopopulation and phytocenotic indices, tailing pond, vegetation study.

\section{INTRODUCTION}

Surface mining has a major impact on the environment. This alterates the landscape, affects the integrity of the habitat and ecosystem functions, influence negatively the quality of air and soil, leads to loss of soil structure and fertility, change the hydrology of the area, is a source of water contamination with toxic substances from tailings ponds (Miller and Zegree, 2014; Mummey et al., 2002; Isosaari and Silanpaa, 2010; Li, 2006; Ramani, 2012).

Van Herck et al. (2000) underlines the risk of storage in ponds facilities contamination through groundwater with heavy metals. In the area of Murcia (Spain), land holdings adjacent mining become unsuitable for agriculture because of contamination with heavy metals (Clemente et al., 2007).

Quantities of tailings resulting from mining activities are immense. Adiansyah et al. (2005) estimates these quantities reach the value of 10 billion tones each year. To these are added the sterile layers resulted from historical mining pollution.

Managing the mining sterile is a great challenge for the protection of the environment. Chemical and physical methods of treatment are 
very expensive. Numerous studies show that the phytoremediation of tailings ponds remains the most efficient remedial method "in situ" for both organic and inorganic pollutants (Dary et al., 2010; Glick, 2010; Mendez et Mayer, 2008).

In the case of tailing ponds and heap of debris, the regrass process is stabilizing the soil. In this way the global risk of pollution with mine waste is reduced (Pourrut et al., 2011, Teixera et al., 2011). Plants decrease the air dispersion, and their roots limit the transfer risk of polluters to other compartments of the ecosystem and also lower soil erosion (Hartley et al., 2012; Huot et al., 2015). Passive and active tehniques can be used for the phytoremediation of ponds and heap. Passive techniques involve the elimination of anthropogenic disturbance and spontaneous regrass of the pond (Hodacova and Prach, 2003). The active techniques accelerate the ecosystem rehabilitation and shall consist of the following: chemical fertilizers application (Holmes, 2001; Daws et al., 2013), revegetation by sowing or plantation (Holl and Aide, 2011), and by covering with a green layer (Ferreira et al., 2015; Cristescu et al., 2012). A major problem of ponds revegetation by artificial insemination is given by the plant resistance to heavy metals.

Several experiments were performed in which different species of plants on tailing ponds with mining sterile rich in zinc, copper, lead, cadmium were involved. The results showed that for the rehabilitation are preferred native species tolerant to heavy metals, instead of ones from other environments (Lan et al., 1997; Berti and Cunningham, 2000; Wang et al., 2007; Blidar, 2009; Muszynska et al., 2013). Ciarkowska et al, 2017 mentioned risk foreign species for native species. The same authors recommended the application of amendments on tailing ponds for the acceleration of ecological succession.

Although Romania benefits from significant funding for the rehabilitation of tailings ponds, many tailing ponds have remained outside rehabilitation operations (Maxim et al., 2015; Maxim et al., 2016; Maxim et al., 2017). In this situation, there is also the tailings pond in Bozanta, Maramures County. Therefore, it has been created the possibility to study the vegetation that has been installed on the natural way, on this pond.

\section{MATERIALS AND METHODS}

The objective of this study was to carry out a vegetation study at the Bozanta's tailing pond, located $5 \mathrm{~km}$ away from Baia Mare municipality. The pond is one of champaign, was operating between 1976 and 2006 and has an area of 60 ha. The scroll is from flotation and comes from the processing of ores containing non-ferrous and precious metals from five mines located in the area.

The vegetation investigation was udertaking using botanical determinants and planimetric method. The observations were made during 2016-2017. Plant species have been identified and the following phytopathogenic indices: presence (the raw table), class of presence (5), abundancedominance $(\%)$, frequency (\%), the average of abundance-dominance (\%), were calculated using the method described by Maxim et al. (2005).The crest of the tailing pond is occupied in a ratio of $35 \%$ by the body of water, $30 \%$ is covered with vegetation and the remaining $35 \%$ is represented by tailings.For the chemical properties of the soil and tailings from Bozanta's tailing pond, samples have been taken from different places considered representative, on the crest of the pond and the sample depth has not exceeded 30 $\mathrm{cm}$. The following physico-chemical analyses: $\mathrm{pH}$, Nitrogen, Phosphorus, Potassium, Humus content have been conducted. The measurement units used for expressing results were: ppm for $\mathrm{P}$ and $\mathrm{K}, \%$ for $\mathrm{N}$ and Humus, and a scale of 1-14 for $\mathrm{pH}$ values.

\section{RESULTS AND DISCUSSIONS}

From the vegetation studies that were carried out on the crest of the Bozanta's tailing pond, floral inventory showed the presence of 40 species, as follows: 6 species of trees, 4 species of shrubs and 30 grass species, as shown in Tab. 1. In details the tree species found are: Betula pendula (14), Salix caprea (11), Populus alba (9), Robinia pseudacacia (4), Quercus robur (3) și Prunus padus (2). Four shrub species were present namely: Rubus fructicosus (3), Rosa canina (3), Viburnum rhytidophyllum (2) și Rubus idaeus (2). The grass vegetation on the crest of the tailing pond was represented by 20 species: Phragmites australis (16), Rumex acetosella (9), Polytrichum commune (7), Tussilago farfara (6), Rhinanthus minor sp (6), Poa pratensis (5), 
Equisetum arvense (5), Nardus stricta (5), Apera spica-venti (5), Calamagrostis arundinacea subsp. Brachytricha (5), Festuca rubra (4) Stellaria media (4), Sorgum halepense (4), Solanum nigrum (4), Setaria glauca (4), Agropyrum repens (3), Achillea millefolium (3), Erigeron canadensis (3), Rorippa sylvestris (3), Scirpus maritimus (2), Chenopodium album (2), Crepis biennis (2), Frangula alnus (2), Taraxacum officinalis (2), Juncus trifidus (2), Polygonum chinense (2), Polygonum lapathifolium (2), Solidago canadensis (1), Erigeron annuus (1) and Tragopogon orientalis (1). In parenthesis, after each species, is listed the presence. Overall, the analysis of plant species presence revealed that the trees presence varied between 2 and 14 markers, out of the 20. In case of shrubs, the presence was 3 in Rubus fructicocus and Rosa canina, and 2 in Viburnum rhytidophyllum and Rubus idaeus. In herbaceous plants, the values of this indicator ranged between much larger values, from 16 for Phragmites australis up to 1 for Solidago canadensis, Erigeron annuus, Tragopogon orientalis. These native species have showed tolerance to heavy metals, which is in line with the research carried out by the Bradshow et al. (1978), Hao et al. (2004) and Parraga-Aguado et al. (2014), who recommended native species instead of exotic plants for the tailings ponds rehabilitation. The frequency of the species along with the 5 classes of presence and the average of abundance-dominance are transposed in Tab. 2 . Regarding the trees, the most widespread species was Betula pendula, with a frequency of $70 \%$, followed by Salix caprea with 55\%, Populus alba with $45 \%$, Robinia pseudacacia with $20 \%$, Quercus robur with $15 \%$ and Prunus padus with $10 \%$.

Shrubs are found in $15 \%$ of the surveys at Rubus fructicosus, Rosa canina and in 10\% of them at Viburnum rhytidophyllum and Rubus idaeus. The most widespread herbaceous species on the crest of the tailing pond at Bozanta, was Phragmites australis which had a frequency of $80 \%$ of the surveys, followed by Rumex acetosela (45\%), Polytrichum commune (35\%), Tussilago farfara (30\%) and Rhinanthus minor (30\%). The same 25\% frequency was found for Poa pratensis, Equisetum arvense, Nardus stricta, Apera spica venti and Calamagrostis arundinacea subsp. Brachytricha while Festuca rubra, Stellaria media, Sorghum halepense, Solanum nigrum and Setaria glauca were found with $20 \%$. Lower frequencies of
15\% were revealed for Agropyrum repens, Achillea millefolium, Erigerom canadensis and Rorippa sylvestris. Other species such as Scirpus maritimus, Chenopodium album, Crepis biennis, Frangula alnus, Taraxacum officinalis, Juncus trifidus, Polygonum chinense and Polygonum lapathifolium had a frequency of $10 \%$ of the surveys. The lowest frequency (5\%) was determined for Solidago canadensis, Erigeron annuus and Tragopogon orientalis with $5 \%$. Regarding the trees species, the first one, Betula pendula belonged the Class IV of presence, two plant species Salix caprea and Populus alba fitted into the Class III of presence and the last three namely, Robinia pseudocacia, Quercus robur and Prunus padus were part of the Class I of presence. Furthermore, all four shrubs Rubus fructicosus, Rosa canina, Viburnum rhytidophyllum , and Rubus idaeus had fallen into the Class I of presence. Results from this study regarding the herbaceous species showed tha Phragmites australis had fallen under the Class V of presence, Rumex acetosela in class III, and Polytrichum commune, Tussilago farfara, Rhinanthus minor sp., Poa pratensis, Equisetum arvense, Nardus stricta, Apera spica venti, Calamagrostis arundinacea subsp. Brachytricha (Steud.) had fallen into in the Class II of presence.

Finally, several herbaceous species had fallen in Class I of presence falls namely, Festuca rubra, Stellaria media, Sorghum halepense, Solanum nigrum, Setaria glauca, Agropyrum repens, Achillea millefolium, Erigeron canadensis, Rorippa sylvestris, Scirpus maritimus, Chenopodium album, Crepis biennis, Frangula alnus, Taraxacum officinalis, Juncus trifidus, Polygonum chinense, Polygonum lapathifolium, Solidago canadensis, Erigeron annuus and Tragopogon orientalis.

As far as the classes of presence are concerned, of the 12 herbaceous species, one belonged to the fifth class (Phragmites australis), one had fallen in class III (Rumex acetosela), five species were placed in class II namely, Polytrichum commune, Tussilago farfara, Poa pratensis, Apera spica venti, Calamagrostis arundinacea subsp. Brachytricha and the last five herbal species Stellaria media, Setaria glauca, Erigerom canadensis, Juncus trifidus and Polygonum chinense belonged to the class I of presence.

The average abundance-dominance indicated that the major coverage at tree species was found for Betula pendula (43.7\%) and Salix 
Table 1. Plant species identified, number of surveys and presence values, in the period 2016-2017, on the crest of Bozanta's tailing pond (1976-2006) located in Maramureș County - Romania

\begin{tabular}{|c|c|c|c|c|c|c|c|c|c|c|c|c|c|c|c|c|c|c|c|c|c|}
\hline \multirow{2}{*}{ Species } & \multicolumn{20}{|c|}{ Survey no. } & \multirow{2}{*}{ Presence } \\
\hline & 1 & 2 & 3 & 4 & 5 & 6 & 7 & 8 & 9 & 10 & 11 & 12 & 13 & 14 & 15 & 16 & 17 & 18 & 19 & 20 & \\
\hline \multicolumn{22}{|l|}{$\underline{\text { Trees }}$} \\
\hline Betula pendula & 4 & 3 & 4 & - & 4 & - & 4 & 4 & 4 & - & 3 & 4 & 4 & - & 3 & 4 & - & 4 & - & 3 & 14 \\
\hline Salix caprea & 3 & - & 2 & 3 & - & - & 3 & - & 3 & 2 & - & - & 3 & 3 & - & 2 & - & 3 & - & 3 & 11 \\
\hline Populus alba & - & - & 1 & $r$ & - & 2 & + & - & 1 & - & - & 1 & - & 2 & - & 1 & - & 1 & - & - & 9 \\
\hline Robinia pseudacacia & $\mathrm{r}$ & - & - & - & $r$ & - & - & - & - & - & - & - & $\mathrm{r}$ & - & - & $\mathrm{r}$ & - & - & - & - & 4 \\
\hline Quercus robur & - & - & - & - & - & $\mathrm{r}$ & - & - & - & - & - & - & - & $\mathrm{r}$ & - & - & - & $\mathrm{r}$ & - & - & 3 \\
\hline Prunus padus & - & - & - & - & - & $\mathrm{r}$ & - & - & - & - & - & - & - & $\mathrm{r}$ & - & - & - & - & - & - & 2 \\
\hline \multicolumn{22}{|l|}{ Shrubs } \\
\hline Rubus fructicosus & - & - & - & $\mathrm{r}$ & - & - & - & - & - & - & - & $\mathrm{r}$ & - & - & - & - & $\mathrm{r}$ & - & - & - & 3 \\
\hline Rosa canina & - & - & - & - & - & - & $\mathrm{r}$ & - & - & - & - & $\mathrm{r}$ & - & - & - & - & - & - & $\mathrm{r}$ & - & 3 \\
\hline Viburnum rhytidophyllum & - & - & - & - & $\mathrm{r}$ & - & - & - & - & - & - & - & $\mathrm{r}$ & - & - & - & - & - & - & - & 2 \\
\hline Rubus idaeus & - & - & - & - & - & - & $\mathrm{r}$ & - & - & - & - & - & - & - & - & $\mathrm{r}$ & - & - & - & - & 2 \\
\hline \multicolumn{22}{|l|}{ Herbaceous plants } \\
\hline Phragmites australis & 5 & 5 & - & 4 & 4 & - & 5 & 5 & 4 & 5 & 4 & 5 & - & 5 & 5 & 4 & - & 4 & 4 & 5 & 16 \\
\hline Rumex acetosella & $\mathrm{r}$ & $\mathrm{r}$ & - & + & $r$ & - & - & $r$ & - & $\mathrm{r}$ & - & - & $\mathrm{r}$ & - & $\mathrm{r}$ & - & - & - & $\mathrm{r}$ & - & 9 \\
\hline Polytrichum commune & + & - & + & - & 1 & - & - & + & - & - & + & - & - & - & - & 1 & - & - & + & - & 7 \\
\hline Tussilago farfara & - & + & - & - & + & - & - & $\mathrm{r}$ & - & $\mathrm{r}$ & - & - & - & - & + & - & - & - & + & - & 6 \\
\hline Rhinanthus minor $s p$ & + & - & - & + & - & - & - & - & $\mathrm{r}$ & - & - & + & - & - & + & - & - & $\mathrm{r}$ & - & - & 6 \\
\hline Poa pratensis & $\mathrm{r}$ & - & - & - & + & $\mathrm{r}$ & - & - & - & - & + & - & - & - & - & - & $\mathrm{r}$ & - & - & - & 5 \\
\hline Equisetum arvense & - & - & $\mathrm{r}$ & - & - & $\mathrm{r}$ & - & - & - & - & $\mathrm{r}$ & - & - & - & $\mathrm{r}$ & - & - & $\mathrm{r}$ & - & - & 5 \\
\hline Nardus stricta & $\mathrm{r}$ & - & - & $\mathrm{r}$ & - & - & - & - & - & $\mathrm{r}$ & - & - & - & - & - & $\mathrm{r}$ & - & - & $\mathrm{r}$ & - & 5 \\
\hline Apera spica-venti & - & - & - & $\mathrm{r}$ & - & - & - & - & $\mathrm{r}$ & - & - & $\mathrm{r}$ & - & $\mathrm{r}$ & - & - & - & - & - & $\mathrm{r}$ & 5 \\
\hline $\begin{array}{l}\text { Calamagrostis arundinacea } \\
\text { subsp. Brachytricha }\end{array}$ & $\mathrm{r}$ & - & - & - & $\mathrm{r}$ & - & - & - & - & $\mathrm{r}$ & - & - & - & - & $\mathrm{r}$ & - & - & $\mathrm{r}$ & - & - & 5 \\
\hline Festuca rubra & - & $\mathrm{r}$ & - & - & - & - & $\mathrm{r}$ & - & - & - & - & - & $\mathrm{r}$ & - & - & - & - & $\mathrm{r}$ & - & - & 4 \\
\hline$\underline{\text { Stellaria media }}$ & - & - & - & $\mathrm{r}$ & - & - & - & $\mathrm{r}$ & - & - & - & - & - & $\mathrm{r}$ & - & - & - & - & $\mathrm{r}$ & - & 4 \\
\hline Sorghum halepense & $\mathrm{r}$ & - & - & - & - & - & + & - & - & - & $\mathrm{r}$ & - & - & - & - & $\mathrm{r}$ & - & - & - & - & 4 \\
\hline Solanum nigrum & - & $\mathrm{r}$ & - & - & $\mathrm{r}$ & - & - & - & - & $\mathrm{r}$ & - & - & - & - & - & - & $\mathrm{r}$ & - & - & - & 4 \\
\hline Setaria glauca & $\mathrm{r}$ & - & - & - & - & $\mathrm{r}$ & - & - & - & - & - & - & $\mathrm{r}$ & - & - & - & - & - & - & $\mathrm{r}$ & 4 \\
\hline Agropyrum repens & - & - & - & - & - & - & - & r & - & - & - & $\mathrm{r}$ & - & - & - & - & - & $\mathrm{r}$ & - & - & 3 \\
\hline Achillea millefolium & - & - & - & $r$ & - & - & - & - & - & - & $\mathrm{r}$ & - & - & - & - & - & - & - & $\mathrm{r}$ & - & 3 \\
\hline$\underline{\text { Erigeron canadensis }}$ & - & - & - & $\mathrm{r}$ & - & $r$ & - & - & - & - & - & - & - & - & - & $\mathrm{r}$ & - & - & - & - & 3 \\
\hline Rorippa sylvestris & - & - & $\mathrm{r}$ & - & - & - & - & $\mathrm{r}$ & - & - & - & - & - & $\mathrm{r}$ & - & - & - & - & - & - & 3 \\
\hline Scirpus maritimus & - & - & $\mathrm{r}$ & - & - & - & - & - & - & - & - & - & - & - & - & - & - & $\mathrm{r}$ & - & - & 2 \\
\hline Chenopodium album & - & - & - & - & $\mathrm{r}$ & - & - & - & - & - & - & - & - & - & - & - & $\mathrm{r}$ & - & - & - & 2 \\
\hline Crepis biennis & - & - & - & - & - & - & - & $\mathrm{r}$ & - & - & - & - & - & - & $\mathrm{r}$ & - & - & - & - & - & 2 \\
\hline Frangula alnus & - & - & - & - & $\mathrm{r}$ & - & - & - & - & - & - & - & $\mathrm{r}$ & - & - & - & - & - & - & - & 2 \\
\hline Taraxacum officinalis & - & - & - & - & - & - & + & - & - & - & - & - & - & - & $\mathrm{r}$ & - & - & - & - & - & 2 \\
\hline Juncus trifidus & - & - & - & - & - & - & $\mathrm{r}$ & - & - & - & - & - & - & - & - & - & $\mathrm{r}$ & - & - & - & 2 \\
\hline Polygonum chinense & - & - & - & - & - & - & - & $r$ & - & - & - & - & $\mathrm{r}$ & - & - & - & - & - & - & - & 2 \\
\hline Polygonum lapathifolium & - & $\mathrm{r}$ & - & - & - & - & - & - & - & - & - & $\mathrm{r}$ & - & - & - & - & - & - & - & - & 2 \\
\hline Solidago canadensis & - & - & - & - & - & - & - & $r$ & - & - & - & - & - & - & - & - & - & - & - & - & 1 \\
\hline Erigeron annuus & - & - & - & - & - & - & - & - & - & - & - & - & - & - & $\mathrm{r}$ & - & - & - & - & - & 1 \\
\hline Tragopogon orientalis & - & - & - & - & - & - & - & - & - & - & $\mathrm{r}$ & - & - & - & - & - & - & - & - & - & 1 \\
\hline
\end{tabular}


Table 2. Frequency, class presence and average abundance-dominance of plant species during 20162017on the crest of Bozanta's tailing pond (1976-2006) located in Maramureș County,

\begin{tabular}{|c|c|c|c|}
\hline Species & Frequency (\%) & Class of presence & ADm (\%) \\
\hline \multicolumn{4}{|l|}{ Trees } \\
\hline Betula pendula & 70 & IV & 43.7 \\
\hline Salix caprea & 55 & III & 20.6 \\
\hline Populus alba & 45 & III & 16.8 \\
\hline Robinia pseudacacia & 20 & $\mathrm{I}$ & 1.1 \\
\hline Quercus robur & 15 & I & 0.82 \\
\hline Prunus padus & 10 & I & 0.55 \\
\hline \multicolumn{4}{|l|}{ Shrubs } \\
\hline Rubus fructicosus & 15 & $\mathrm{I}$ & 0.82 \\
\hline Rosa canina & 15 & $\mathrm{I}$ & 0.82 \\
\hline Viburnum rhytidophyllum & 10 & I & 0.55 \\
\hline Rubus idaeus & 10 & I & 0.55 \\
\hline \multicolumn{4}{|l|}{ Herbaceous plants } \\
\hline Phragmites australis & 80 & $\mathrm{~V}$ & 70.0 \\
\hline Rumex acetosela & 45 & III & 16.8 \\
\hline Polytrichum commune & 35 & II & 6.10 \\
\hline Tussilago farfara & 30 & II & 5.25 \\
\hline Rhinanthus minor $s p$ & 30 & II & 5.25 \\
\hline Poa pratensis & 25 & II & 4.37 \\
\hline Equisetum arvense & 25 & II & 4.37 \\
\hline Nardus stricta & 25 & II & 4.37 \\
\hline Apera spica venti & 25 & II & 4.37 \\
\hline Calamagrostis arundinacea subsp. Brachytricha (Steud.) & 25 & II & 4.37 \\
\hline Festuca rubra & 20 & I & 1.1 \\
\hline Stellaria media & 20 & I & 1.1 \\
\hline Sorghum halepense & 20 & I & 1.1 \\
\hline Solanum nigrum & 20 & I & 1.1 \\
\hline Setaria glauca & 20 & I & 1.1 \\
\hline Agropyrum repens & 15 & I & 0.82 \\
\hline Achillea millefolium & 15 & I & 0.82 \\
\hline Erigerom canadensis & 15 & $\mathrm{I}$ & 0.82 \\
\hline Rorippa sylvestris & 15 & I & 0.82 \\
\hline Scirpus maritimus & 10 & I & 0.55 \\
\hline Chenopodium album & 10 & I & 0.55 \\
\hline Crepis biennis & 10 & I & 0.55 \\
\hline Frangula alnus & 10 & I & 0.55 \\
\hline Taraxacum officinalis & 10 & I & 0.55 \\
\hline Juncus trifidus & 10 & I & 0.55 \\
\hline Polygonum chinense & 10 & I & 0.55 \\
\hline Polygonum lapathifolium & 10 & $\mathrm{I}$ & 0.55 \\
\hline Solidago canadensis & 5 & $\mathrm{I}$ & 0.27 \\
\hline Erigeron annuus & 5 & $\mathrm{I}$ & 0.27 \\
\hline Tragopogon orientalis & 5 & $\mathrm{I}$ & 0.27 \\
\hline
\end{tabular}


caprea $(20.6 \%)$, and for the herbaceous species Phragmites australis (70.0\%). Comparing the research carried out by Maxim et al. (2016) and Maxim et al. (2017) at two mining tailings pond (iron ores) from Capusu Mare located in Cluj county, we noticed some similarities but also differences between the vegetation installed on this tailings ponds and the one at Bozanta.

Thus, at the first tailing pond from Capusu Mare, after 40 years since the heap was closed, the woody species with highest mean abundancedominance were found to be: Hippophae rhamnoides $(\mathrm{ADm}=18.7 \%)$, Salix alba $(\mathrm{ADm}=$ $18.4 \%)$, Populus tremula (ADm $=14.1 \%)$ and Robinia pseudacacia (ADm $=14.5 \%)$. At the second tailing pond closed 34 years ago, the most widespread wood species were found to be Hippophae rhamnoides $(\mathrm{ADm}=14.78 \%)$ and Salix alba (ADm = 10.55\%). Instead, at Bozanta, the highest values of the mean abundancedominance were found for Betula pendula (ADm $=43.7 \%)$ and Salix capraea (ADm $=20.6 \%)$, as can be seen, other than those identified at Capusu Mare. About herbaceous plants, at both Capusu Mare and Bozanta, the most abundant species was Phragmites australis.

Cover vegetation of tailings pond at Bozanta was found to be $30 \%$, while those from Capusu Mare were 77\% (after 34 years), respectively 82\% (after 40 years). We therefore, appreciate that the space with vegetation cover is approximately the same if we consider that at Bozanta, the tailing pond was closed 12 years ago.

The physico-chemical test results indicated very wide intervals (2.65-7.28) for the $\mathrm{pH}$. Phos- phorus quantities were found varying between 2-75 ppm while Potassium between 12-112 ppm and humus content ranged between 1.65-6.86\%. Insignificant quantities (0.02-0.49\%) of nitrogen were determined. Besides, nitrogen content was comparable to that found by Ye et al. (2002) in the useless rock from the northern part of Guangdong, in southern China, respectively 0.016-0.075\%. Waste heap comes from the exploitation of minerals rich in zinc and plumb. The amount of humus is noticeably higher at tailing pond studied by us (1.65-6.86\%) compared to the ponds of Guangdong, where the values of this parameter had vacillated between 0.58 and $1.78 \%$

For the determination of heavy metals from the soil were taken two samples of soil and one of waste rock. In the three sample have been determined the presence and the concentration of the following heavy metals: $\mathrm{Cd}, \mathrm{Pb}, \mathrm{Ni}, \mathrm{Cr}$. In Tab. 3 are given the concentrations of heavy metals, but also the normal values, alert threshold, where the authorities have to start monitoring the pond. The intervention thresholds, when the authorities will take steps to reduce concentrations to the normal value, are also mentioned.

The results obtained showed that in the case of lead and chromium the concentrations are two and a half higher than normal values, but in neither of these cases the alert thresholds have not been yet achieved. This had allowed the installation of a variety of vegetation on the tailing pond. Even though we cannot exclude that, probably, at depths higher than $30 \mathrm{~cm}$, the concentration of heavy metals could be larger.

Table 3. Concentration of heavy metals at Bozanta tailing pond located in Maramures County (2007) determined by chemical analysis

\begin{tabular}{cccccccccc}
\hline & & \multicolumn{3}{c}{$\begin{array}{c}\text { Concentration of } \\
\text { samples }\end{array}$} & & \multicolumn{3}{c}{ Benchmark } \\
\cline { 3 - 10 } $\begin{array}{c}\text { Chemical } \\
\text { tracer }\end{array}$ & UM & & & & Order nr. 756 from 3 november 1997) & Normal \\
\cline { 3 - 10 } & & v1 & P2 & P3 & $\begin{array}{c}\text { Alert threshold } \\
\text { value }\end{array}$ & $\begin{array}{c}\text { Sensitive } \\
\text { areas }\end{array}$ & $\begin{array}{c}\text { Less } \\
\text { sensitive } \\
\text { areas }\end{array}$ & $\begin{array}{c}\text { Sensitive } \\
\text { areas }\end{array}$ & $\begin{array}{c}\text { Less } \\
\text { sensitive } \\
\text { areas }\end{array}$ \\
\hline $\mathbf{C d}$ & $\mathrm{mg} / \mathrm{kg}$ & 0.14 & 0.20 & 0.21 & 1 & 3 & 5 & 5 & 10 \\
\hline $\mathbf{P b}$ & $\mathrm{mg} / \mathrm{kg}$ & 39.73 & 59.77 & 37.95 & 20 & 50 & 250 & 100 & 1000 \\
\hline $\mathbf{N i}$ & $\mathrm{mg} / \mathrm{kg}$ & 13.52 & 11.59 & 9.18 & 20 & 75 & 200 & 150 & 500 \\
\hline $\mathbf{C r}$ & $\mathrm{mg} / \mathrm{kg}$ & 50.16 & 68.96 & 57.18 & 30 & 100 & 300 & 300 & 600 \\
\hline
\end{tabular}


The concentration of heavy metals at the tailing pond from Bozanta were found to be significantly smaller compared to those of manganese mines in the northern city of Xiangtan from Hunan province, China. There, cadmium from the waste rock was $119 \mathrm{mg} / \mathrm{kg}$, manganese was 31903 $\mathrm{mg} / \mathrm{kg}$, copper was $126 \mathrm{mg} / \mathrm{kg}$, and the zinc was $2490 \mathrm{mg} / \mathrm{kg}$. Wang et al. (2007) assigned to these high concentrations of heavy metals the absence of vegetation on the tailings ponds. The same conclusion was drawn earlier by Lan et al. (1997) at lead/zinc mines of Shaoguan, from southern China stating that the natural colonization with plant species on these ponds was impeded by the high concentrations of lead $(34300 \mathrm{mg} / \mathrm{kg})$, zinc $(36500 \mathrm{mg} / \mathrm{kg})$, copper $(251 \mathrm{mg} / \mathrm{kg})$ and cadmium (83 mg/kg).

\section{CONCLUSION}

The observations were made during 20162017 at Bozanta's tailing pond, Maramures County, after 11-12 years from the closure of the pond.

The pond is one of champaign, was operating between 1976 and 2006 and covers an area of 60 ha. The scroll is from flotation and comes from the processing of ores containing non-ferrous and precious metals from five mines located in the area.

Floral studies showed the presence of 40 species, of which 6 species of trees, 4 species of shrubs and 30 grass species.

After 11 years since the pond was closed, vegetation coverage was found to be of $30 \%$, the body of water occupies approximately $35 \%$ of the area and the remaining 35\% was found to be represented by tailings. The mean abundancedominance indicated that the major coverage at tree species level was represented by Betula pendula (55.3\%) and Salix caprea (32\%), and at herbaceous species level by Phragmites australis (78.8\%).

The physico-chemical test results indicated very wide intervals of $\mathrm{pH}$ (2.65-7.28), Phosphorus (2-75 ppm), Potassium (12-112 ppm) and Humus (1.65-6.86\%), as well as insignificant quantities of Nitrogen (0.02-0.49\%). For lead and chromium the concentrations were found to be two and a half higher than the normal values, but in neither of these cases, the alert of thresholds have not been yet achieved, which surely allowed the installation plant species.

\section{REFERENCES}

1. Adiansyah JS, Rosano M, Vink S, Keir G (2015). A framework for a sustainable approach to mine tailings management: disposal strategies. J. Clean. Prod., 108:1050e1062.

2. Berti WR, Cunningham SC (2000). Phytostabilization of metals. In: Raskin, I., Ensley, B.D. (Eds.), Phytoremediation of Toxic Metals: Using Plants to Clean up the Environment. John Wiley and Sons, New York.

3. Blidar CF, Pop L, Petrus-Vancea A (2009). Enzymological study of the evolution of the technogenic soil submitted to biological recultivation in Bozanta Mare (Maramures County, North-Western Romania). An U din Oradea, Fasc. Biol., 16 (2): $32 \mathrm{e} 35$.

4. Bradshaw AD, Humphreys MO, Johnson MS, (1978). The value of heavy metal tolerance in the revegetation of metalliferous mine wastes. In: Goodman, G.T., Chadwick, M.J. (Eds.), Environmental Management of Mineral Wastes. Sijthoff and Noordhoff, The Netherlands.

5. Ciarkowska K, Hanus-Fajerska E, Gambuś F, Muszyńska E, Czech T (2017). Phytostabilization of $\mathbf{Z n - P b}$ ore flotation tailings with Dianthus carthusianorum and Biscutella laevigata after amending with mineral fertilizers or sewage sludge. J. Environ. Manag., 189:7583.

6. Clemente R, Paredes C, Bernal MP (2007). A field experiment investigating the effects of olive husk and cow manure on heavy metal availability in a contaminated calcareous soil from Murcia (Spain). Agr. Ecosyst. Environ., 118: 319-326.

7. Cristescu RH, Frere C, Banks PB (2012). A review of fauna in mine rehabilitation in Australia: current state and future directions. Biol. Conserv., 149: 60-72.

8. Dary M Chamber-Perez M, Palomares A, Pajuelo E (2010). "In situ" phytostabilisation of heavy metal polluted soils using Lupinus luteus inoculated with metal resistant plant-growth promoting rhizobacteria. J. Hazard. Mater., 177:323-330.

9. Daws MI, Standish RJ, Koch JM, Morald TK (2013). Nitrogen and phosphorus fertilizer regime affect jarrah forest restoration after bauxite mining in Western Australia. Appl. Veg. Sci., 16:610-618.

10. Glick BR (2010). Using soil bacteria to facilitate phytoremediation. Biotechnol. Adv., 28:367-374.

11. Ferreira MC, Walter BMT, Vieira DLM (2015). Topsoil translocation for Brazilian savanna restoration: propagation of herbs, shrubs, and trees. Restor. Ecol., 23:723-728.

12. Hao XZ, Zhou DM, Si YB (2004). Revegetation of copper mine tailings with ryegrass and willow. Pedosphere, $14: 283 \mathrm{e} 288$.

13. Hartle W, Dickinson NM, Riby P, Shutes B (2012). Sustainable ecological restoration of brownfield sites through engineering or managed natural attenuation? A case study from Northwest England. Ecol. Eng., 40:70-79.

14. Hodacova D, Prach K (2003). Spoil heaps from brown coal mining: technical reclamation versus spontaneous revegetation. Restor. Ecol., 11:385-391. 
15. Holl KD, Aide TM (2011). When and where to actively restore ecosystems. For. Ecol. Manag., 261: 1558-1563

16. Holmes PM (2001). Shrubland restoration following woody alien invasion and mining: effects of topsoil depth, seed source, and fertilizer addition. Restor. Ecol., 9:71-84

17. Huot H, Séré S, Charbonnier P, Simonnot MO, More, JL (2015). Lysimeter monitoring as assessment of the potential for revegetation to manage former iron industry settling ponds. Science of the Total Environment, 526:2940

18. Isosaari P, Sillanpää M (2010). Electromigration of arsenic and co-existing metals in mine tailings. Chemosphere, 81:1155-1158.

19. Lan CY, Shu WS, Wong MH (1997). Revegetation of lead/ zinc mine tailings at Shaoguan, Guangdong Province, China: Phytotoxicity of the tailings D.L. Wise (Ed.), Global Environmental Biotechnology, Elsevier Science.

20. Li MS (2006). Ecological restoration of mineland with particular reference to the metalliferous mine wasteland in China: a review of research and practice. Sci. Total Environ., 357:38-53.

21. Maxim A, Stoie A, Șandor M, Odagiu A, Pertea V, Mihalescu L, (2015). The Natural Rehabilitation of Tailing Ponds from Căpuș, Cluj. Bull. UASMV Cluj-Napoca, Agriculture, 72 (1):154-160

22. Maxim A, Șandor M, Opincariu A, Perțea V, Mihalescu L, Roman V (2016). Technogenic Ecological Sequences in Mine Tailings from Căpușu Mare, Built between 19691975. ProEnvironment, 9: 435441.

23. Maxim A, Șandor M, Opincariu A, Mihalescu L, Roman V, Bâlc L (2017). Technogenic Ecological Sequences in Tailing Pond from Căpușu Mare, Built between 19751981. Bulletin USAMV Cluj-Napoca, series Agriculture, 74(2):95-100.

24. Mendez MO, Maier RM (2008). Phytoremediation of mine tailings in temperate and arid environments. Rev. Environ. Sci. Biotechnol., 7 (1):47-59.
25. Miller A, Zégre N (2014). Mountaintop removal mining and catchment hydrology. Water, 6: 472-499.

26. Mummey DL, Stahl PD, Buyer JS (2002). Soil microbiological properties 20 years after surface mine reclamation: spatial analysis of reclaimed and undisturbed sites. Soil Biol. Biochem., 34:1717-1725.

27. Muszynska E, Hanus-Fajerska E, Ciarkowska K (2013). Evaluation of seed germination ability of native calamine plant species on different substrata. Pol. J. Environ. Stud., 22 (6):1775e1780.

28. Parraga-Aguado, Querejeta JI, Gonzalez-Alcaraz MN, Jimenez-Carceles FJ, Conesa HM (2014). Usefulness of pioneer vegetation for the phytomanagement of metal(loid)s enriched tailings: grasses vs. shrubs vs. trees. J. Environ. Manag., 133:51e58.

29. Pourrut B, Lopareva-Pohu A, Pruvot C, Garçon G, Verdin A, Waterlot C, Bidar G, Shirali P, Douay F (2011). Assessment of fly ash-aided phytostabilisation of highly contaminated soils after an 8-year field trial: Part 2. Influence on plants. Sci. Total Environ., 409:4504e4510.

30. Ramani, R.V., 2012. Surface mining technology. Progress and Prospects. Procedia Eng., 46:9-21.

31. Teixeira LAJ, Berton RS, Coscione AR, Saes LA (2011). Biosolids application on banana production: soil chemical properties and plant nutrition. Appl. Environ. Soil Sci.

32. Van Herck P, Vandecasteele C, Swennen R, Mortier R (2000). Zinc and lead removal from blast furnace sludge with a hydrometallurgical process. Environ. Sci. Technol., 34 (17), 3802-3808

33. Wang X, Liu Y, Zeng G, Chai L, Xiao X, Song X, Min Z (2007). Pedological characteristics of Mn mine tailings and metal accumulation by native plants Chemosphere, 72:12601266.

34. Ye ZH, Shu WS, Zhang ZQ Lan CY, Wong MH (2002). Evaluation of major constraints to revegetation of lead/zinc mine tailings using bioassay techniques. Chemosphere, 47:1103-1111. 